LÊDO IVO

\title{
EL SILENCIO*
}

\author{
Lêdo Ivo**
}

\section{EL RADIO MUDO}

El radio está mudo. Y bendigo la falla de la batería

que devuelve el universo a su silencio inicial

y ahuyenta el habla inútil de los hombres.

Ningún rumor en todo el mundo. Ni siquiera el estallido

de una rama en el suelo.

Brasil desaparece.

La guerra y el terror se sumen en el silencio

y la paz del espacio vacío impera en el instante enmudecido

como el péndulo de un reloj de pared

inmovilizado por el tiempo y el cansancio.

La desnudez del radio altera la rutina del día.

Es algo inesperado en este mundo rendido ante el estrépito y el desperdicio, pero tiene su razón de ser.

110 El sol es silencioso e ilumina. El amor solo vale la pena

cuando alcanza la antesala de la adoración y cada gesto es mudo y pausado, y ninguna palabra mancha la perfección del éxtasis.

Las constelaciones están silenciosas.

Bendigo una vez más la batería descompuesta y me arrodillo como si el silencio fuera el último dios que queda en el mundo tras las devastaciones de los hombres y el consumo inmoderado de palabras.

* Traducción de Adrián Chávez.

** Lêdo Ivo (Maceió, 1924-2012) fue parte de la generación del 45. Recibió el Premio Mario de Andrade en 1982 y el Premio Casa de las Américas en 2009. 


\section{EL SILENCIO DEL MUNDO}

El mundo esconde siempre sus secretos en la hoja otoñal que amarillece, en los maderos que dejaron los naufragios, en las grutas, los viaductos, los espejos que nos observan en las peluquerías y nos duplican, aunque múltiples ya éramos. Y yo le digo al mundo: habla, oh gran mudo, que te paras frente a nosotros por la mañana y enfrentas con tu silencio nuestro enorme pasmo de estar vivos. A pesar de los rumores que escurren sobre el día claro que atrae a los navíos, en la noche negra del fornicio, del escarabajo que zumba más allá del bosque, y del fragor de las guerras y del tránsito, el mundo es solo silencio y solo secreto en este largo exilio que comienza con el llanto en la cuna y solo acaba en el misterio de la nada, en el silencio del polvo. 
LÊDO IVO

\section{EL SILENCIO ESPERADO}

Ahora que ya vi la nieve, puedo morir

de una muerte blanca e inmaculada

que reúna la claridad y la sombra

en el vértigo del enlace último.

Con su soplo trémulo y sus labios fríos

es ella el silencio esperado, y sepulta en la tierra

el amor audaz y el sueño imprudente

como quien esconde un pajarito muerto

de los ojos del transeúnte que atraviesa el parque. 